\title{
Strategic Leadership toward Executive Influence on Innovation: A Case for Government Institution
}

\author{
Eva Astriana $^{1}$, Yasmine Nasution ${ }^{2}$ \\ Faculty of Economic and Business, Universitas Indonesia, Depok, Indonesia ${ }^{1,2}$ \\ evaastriana@gmail.com ${ }^{1}$
}

\begin{abstract}
The focus of this research is in the area of strategic leadership in government institution. The objective this study is to examine influence of strategic leadership toward executive influence on innovation in government institution. The research adopted quantitative approach. The result of this research provide evidence to the correlation between strategic leadership and executive influence on innovation. The main conclusion of this study also confirmed previous research that says strategic leadership are able to play an important role in influencing executive influence on innovation in government institution. This study recommends executives of government institution to improve their strategic leadership in order to achieve the maximum effect of innovation in their organization.
\end{abstract}

Keywords: Administration of Innovation; Culture Organization; Executive Influence; Government; Leadership; Strategic Management; Top Management Team.

\section{Introduction}

Government institutions are non-profit organizations that facilitate people in various affairs related to rights and obligations as citizens of the country. Although government institutions are not allowed to prioritize financial benefits but still they are required to always be able to change according to current developments so that they can sustain. Government is also required to be able to innovate. The innovations that are created can be in the form of more organized, clear, and simple administrative and bureaucratic processes, or more interesting theme government buildings, and so on. This can happen if the top management or upper echelons also have creative thoughts. What is happening in the field is government institution that is already carrying out bureaucratic reforms even though it has not optimal. While it is necessary to improve performance and achieve excellence, government institutions are also expected to improve their ability to innovate.

The author has not found a meaningful discovery regarding the relationship of leadership strategy, top management team tenure heterogeneity, and the organizational culture toward the executive influence on innovation. The researches which discussed strategic leadership, tenure heterogeneity of the Top Management Team (TMT), and organizational culture have not examined the extent of their influence in achieving bureaucratic reform seen from the executive influence on innovation. There is a positive relationship between strategic leadership and innovation, management and innovation teams, and also between strategic leadership, top management team, and innovation[1]. There is a positive relationship between leadership and 
innovation, leadership and organizational culture, organizational culture and innovation, and also strategic leadership and organizational culture to innovation[2]. The relationship between organizational culture and innovation[3].

The main objectives of this study are to examine how strategic leadership improve executive influence on innovation and how they are moderated by organizational culture and tenure heterogeneity of the Top Management Team (TMT). We conducted the study in Ministry of Education and Culture in Indonesia. Hopefully, the result will give us strategies on how to achieve bureaucratic reform within government institutions.

\section{Method}

Strategic leadership, tenure heterogeneity of Top Management Team (TMT), and organizational culture have a very important relationship in increasing government institution's innovation and can help achieve bureaucratic reform. Government institutions need the right organizational change throughout bureaucratic reform. Innovation is an element of this change. Government institutions are required to be able to innovate in order to provide comfort and trust to the society. One element that influences innovation is strategic leadership. Organizational leaders help define and shape work contexts that contribute to organizational innovation [4].

Strategic leadership also has an important role in innovation. Similar with tenure heterogeneity of top management team (TMT), The members of the top management team (TMT) also play an important role in the innovation process[5]. Thus, tenure heterogeneity of top management team (TMT) can moderate the relationship of strategic leadership and executive influence of innovation. Furthermore, organizational culture is one of the elements in achieving innovation as well. Top managers' style of management, and their communication style, and incentive systems that being used are some of the determinants of proinnovation organizational culture. A good culture will create an atmosphere that supports employees to be creative while also being assisted by their superiors. It indicates organizational culture can moderate the relationship of strategic leadership and the executive influence of innovation.

In this study, the first independent variable (X1) is strategic leadership. The first moderating variable (M1) is the tenure heterogeneity of the Top Management Team. The second moderating variable (M2) is the organizational culture, and the dependent variable (Y) is executive influence on innovation. The model of this study can be seen in the picture below.

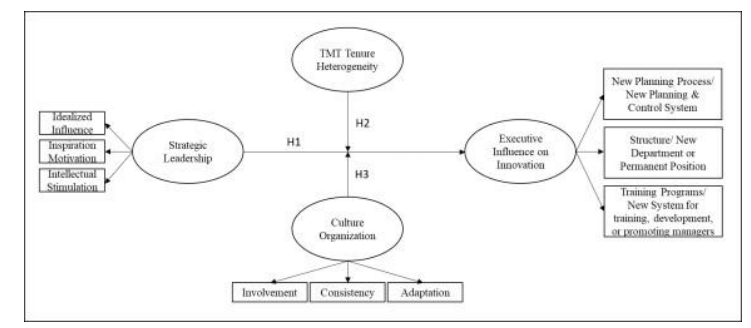

Fig.1. Research Model

Strategic leadership is one element that plays an important role in organizational change. Organizational change occurs one of them is because innovation. One of the main factors repeatedly suggested to influence innovation is leadership [6];[7];[8]. Strategic leaders have been repeatedly recognized for their critical role in identifying opportunities and making decisions that affects innovation process[9]. Today, companies are competing to maintain their market share and their good reputation in the public's eye. Strategic leadership and strategic innovation are very important to achieve and maintain strategic competitiveness in 21 st century 
[10]. Leaders also help define and shape work contexts that contribute to organizational innovation [4]. A good work context and support for innovation will produce good performance for the organization. The executive decisions and organizational actions related to innovation have important strategic implications[11]. Componential theory has provided a model in which 'positive' leadership behaviour influences subordinates' perceptions of leader support, which in turn stimulates creativity, a key factor in the innovation process [12]. There are several ways for leaders to increase the creativity of their subordinates, one of them is by giving promotions and awards, so that employees will always be eager to make something new that can benefit the organization. So the hypothesis that arises is:

Hypothesis 1: Strategic leadership behaviour has a positive effect on executive influence on administrative innovation.

Empirical research and theoretical discussion have indicated that promotion and innovation require top management involvement and support that members of the top management team (TMT) play an important role in the innovation process[10];[13];[5]. The strategic decisions and organizational innovation are strongly influenced by top managers and the external environment context[14]. Thus, the tenure heterogeneity of the Top Management Team (TMT) moderates the effectiveness of innovation strategies[15]:

Hypothesis 2: The relationship between strategic leadership behavior and executive influence on administrative innovation is moderated by the tenure heterogeneity of TMT.

Organizational culture is one of the factors related to leadership and innovation. Leaders can create and manage an organizational culture that promotes innovation, can be a champion of heroic products or innovators who support innovation during the implementation process, and can create organizational structures needed to support innovation [16]. The strategic leadership researches show that top managers influence organizational outcomes by building organizational culture, influencing organizational climate, and building capacity for change and innovation[8]. Previous researches also said that innovation is associated with strong and visionary leadership and a supportive culture [17]. So the next hypothesis is:

Hypothesis 3: The relationship between strategic leadership behavior and executive influence on administrative innovation is moderated by organizational culture.

The research design in this study uses quantitative research that is useful for analyzing the relationships between one variable and another. The data for this study consisted of two sources: primary data such as interviews about innovation and secondary data such as the results of questionnaires and data on employee tenure. Our participants are echelon 2 and 3 officials within the Ministry of Education and Culture in Indonesia who represented their work units. We got samples from 37 work units with 146 respondents. This study used structural equation modeling with Lisrel 8.8 as the tool to analyze the fitness of the model with the data.

\section{Result}

\subsection{Measurements Strategic Leadership}

The Multifactor Leadership Questionnaire (MLQ) is found as one of the best and the most instrument in leadership studies[18]. This MLQ instrument is divided into seven factors, namely ideal influence, inspirational motivation, intellectual stimulation, individual consideration, contingent award, exception management, and laissez faire. Ideal influence factors, inspirational motivation, intellectual stimulation, and individual consideration are the elements of transformational leadership. The contingent and management factors by exceptions represent transactional leadership behavior. Whereas laissez faire is a behavior that is contrary to the core of strategic leadership so that the author does not include it in the instrument of strategic leadership assessment. In this study the author takes three dimensions in strategic leadership 
namely the influence of idealism or charismatic, inspirational motivation, and intellectual stimulation.

\section{a. Top Management Team Tenure Heterogeneity}

In our study, each unit is led by echelon II, which means that is the top management team tenure heterogeneity is the tenure of echelon II. This data is obtained from selfreported employment information provided by respondents.

\section{b. Organizational Culture}

There are four cultural characteristics of an effective organization, namely involvement, consistency, adaptation, and mission[19]. Organizations that effectively empower people, organize around teams, and develop human abilities are definitions of the dimensions of engagement[20]. Everyone at the organizational level feels a strong bond in the organization, they feel they have the leadership and advice that can also influence the organization. The second characteristic is consistency where effective organizations tend to have a "strong" culture that is very consistent, well coordinated, and well integrated[21]. Leaders and followers have the same understanding and are jointly responsible for maintaining stability and integration. One of the characteristic of an adaptive organizational culture is they are driven by their customers, take risks and learn from their mistakes, and have the ability and experience in creating change [22]. The last characteristic is mission: an effective organization has clear goals and direction, defines strategic goals and objectives, and expresses the vision of the future[23];[24];[25].

\section{c. Executive Influence on Innovation}

One source of innovation is the development of new product markets. Other sources of innovation comes from the development of new and more efficient administrative mechanisms: new systems for strategic planning and control, new systems for training, developing managers, and new departments or managerial positions to improve intraorganizational coordination [26]. In this study the author only examined administrative innovations carried out by the public organization of the Ministry of Education and Culture in Indonesia. Administrative innovations have three dimensions, namely the new planning process (new control and planning system), new structures or departments (permanent positions), and new training programs or systems for manager training, development, or promotion.

\section{Discussion}

Based on the questionnaire distributed the respondents' data are obtained as follows from the data above, it can be seen that the number of echelon III male respondents is 81 people (74.3\%) and echelon III female respondents is 28 people $(25.7 \%)$, most of them aged over 46 years old $(79.8 \%)$ with undergraduate education as many as 23 respondents $21.1 \%$ ) and postgraduate as many as 86 respondents (78.9\%). Golongan for echelon III respondents are mostly in group IV/b-IV/c with a percentage of $51.4 \%$.

Table 1. Correspondent Data

\begin{tabular}{|l|l|l|l|l|l|}
\hline \multirow{2}{*}{ No } & \multirow{2}{*}{ Category } & \multicolumn{2}{|c|}{ Echelon III } & \multicolumn{2}{c|}{ Echelon II } \\
\cline { 3 - 6 } & & Total & Percentage & Total & Percentage \\
\hline 1 & Total of sample & 109 & $100 \%$ & 37 & $100 \%$ \\
\hline
\end{tabular}




\begin{tabular}{|c|c|c|c|c|c|}
\hline 2 & $\begin{array}{l}\text { Gender } \\
\text { - Male } \\
\text { - Female }\end{array}$ & $\begin{array}{l}81 \\
28\end{array}$ & $\begin{array}{l}74,3 \% \\
25,7 \%\end{array}$ & $\begin{array}{l}29 \\
8\end{array}$ & $\begin{array}{l}78,4 \% \\
21,6 \%\end{array}$ \\
\hline 3 & $\begin{array}{l}\text { Age } \\
-\quad \leq 25 \text { years old } \\
-\quad 26-30 \text { years old } \\
-\quad 31-35 \text { years old } \\
-\quad 36-40 \text { years old } \\
-\quad 41-45 \text { years old } \\
-\quad \geq \quad 46 \text { years old }\end{array}$ & $\begin{array}{l}1 \\
3 \\
8 \\
4 \\
6 \\
87\end{array}$ & $\begin{array}{l}0,9 \% \\
2,8 \% \\
7,4 \% \\
3,6 \% \\
5,5 \% \\
79,8 \%\end{array}$ & $\begin{array}{l}0 \\
0 \\
0 \\
0 \\
0 \\
37\end{array}$ & $\begin{array}{l}0 \% \\
0 \% \\
0 \% \\
0 \% \\
0 \% \\
100 \%\end{array}$ \\
\hline 4 & $\begin{array}{l}\text { Education } \\
\text { - Undergraduate } \\
\text { - Postgraduate }\end{array}$ & $\begin{array}{l}23 \\
86\end{array}$ & $\begin{array}{l}21,1 \% \\
78,9 \%\end{array}$ & $\begin{array}{l}0 \\
37\end{array}$ & $\begin{array}{l}0 \% \\
100 \%\end{array}$ \\
\hline 5 & $\begin{array}{l}\text { Golongan } \\
\text { - III/b-III/c } \\
\text { - III/d-IV/a } \\
\text { - IV/b-IV/c } \\
\text { - IV/d-IV/e }\end{array}$ & $\begin{array}{l}16 \\
37 \\
56 \\
0\end{array}$ & $\begin{array}{l}14,7 \% \\
33,9 \% \\
51,4 \% \\
0 \%\end{array}$ & $\begin{array}{l}0 \\
0 \\
27 \\
10\end{array}$ & $\begin{array}{l}0 \% \\
0 \% \\
73 \% \\
27 \%\end{array}$ \\
\hline 6 & $\begin{array}{l}\text { Work Period } \\
-\leq 10 \text { years } \\
-11-15 \text { years } \\
-16-20 \text { years } \\
-21-25 \text { years } \\
-26-30 \text { years } \\
-\geq 31 \text { years }\end{array}$ & $\begin{array}{l}12 \\
5 \\
10 \\
22 \\
30 \\
30\end{array}$ & $\begin{array}{l}11,1 \% \\
4,6 \% \\
9,2 \% \\
20,1 \% \\
27,5 \% \\
27,5 \%\end{array}$ & $\begin{array}{l}0 \\
0 \\
1 \\
2 \\
13 \\
21\end{array}$ & $\begin{array}{l}0 \% \\
0 \% \\
2,7 \% \\
5,4 \% \\
35,1 \% \\
56,8 \%\end{array}$ \\
\hline 7 & $\begin{array}{l}\text { Tenure } \\
-<1 \text { year } \\
-1 \text { year } \\
-2 \text { years } \\
-3 \text { years } \\
-4 \text { years } \\
-5 \text { years }\end{array}$ & $\begin{array}{l}0 \\
20 \\
13 \\
2 \\
37\end{array}$ & $\begin{array}{l}0 \% \\
18,3 \% \\
11,9 \% \\
34 \% \\
1,8 \% \\
34 \%\end{array}$ & $\begin{array}{l}1 \\
15 \\
2 \\
19 \\
0 \\
0\end{array}$ & $\begin{array}{l}2,7 \% \\
40,5 \% \\
5,4 \% \\
51,4 \% \\
0 \% \\
0 \%\end{array}$ \\
\hline
\end{tabular}

The working period of echelon III respondents is mostly in the range of 2630 years $(27.5 \%)$ and above 31 years $(27.5 \%)$. While the tenure for echelon III is at most three years $(34 \%)$ and five years (34\%).

Whereas for echelon II respondents the number of male respondents is 29 people $(78.4 \%)$ and female respondents is 8 people (21.6\%) who were all above the age of 46 years old (100\%). All echelon II respondents have a postgraduate education level $(100 \%)$ with golongan in the range IV/b-IV/c of $73 \%$ and IV/d-IV/b of $27 \%$. The working period of echelon II respondents is mostly in the range of over 31 years $(56.8 \%)$. While the term of echelon II is mostly three years $(51.4 \%)$. 
Measurement of the model for each construct tested is called the Confirmatory Factor Analysis (CFA) model. This analysis is useful for testing the suitability of the latent variable with the indicator.

Analysis of the CFA model produces a model validity analysis and model reliability analysis. Standardized Factor Loading (SFL) of all observed variables (indicators) shows values above 0.5 in accordance with Igbaria et.al. (1997)'s suggestion. Thus it can be concluded that the observed variable and indicators are valid. Then, we calculate the value of construct reliability (CR) and Variance Extracted from each dimension, which in overall results in CR values above 0.70 and $\mathrm{VE}$ above 0.5 so that all indicators can be said to be reliable or significant. The model and data have a good fit where GOFI has met the requirements, so it can also be said that the structural model has conformity with some statistical criteria that show good fit ( $\mathrm{p}$-value $=1.00>0.005$, RMSEA $=0.00<0,08$ ).

Strategic leadership has a significant effect to executive influence on innovation (H1 is accepted with a t-value of 4.03) indicating that strategic leadership significantly and positively influence the impact of innovation from the leader. So that it will make it easier for organization to achieve organizational changes where a lot of innovation will be born. Regarding the first moderation variable, $\mathrm{H} 2$ is rejected $(\mathrm{t}$-value $=-0.46)$. It shows that tenure heterogeneity of TMT does not moderate the relationship between strategic leadership and executive influence on administrative innovation. The term of office of each unit leader does not give direct influence, which means that the strategic leadership relationship to administrative innovation is not affected based on how long the leadership period of the unit.

The second moderating variable is also rejected $(\mathrm{H} 3$ is rejected, t-value $=-1.37$ ). Demonstrate that the relationship between strategic leadership behavior and executive influence on administrative innovation is not moderated by organizational culture. The organizational culture in each work unit does not moderating the influence of strategic leadership to the administrative innovation.

\section{Conclusion}

Our study illustrates that the idealized influence from strategic leadership of unit leaders is in a good category, meaning that the leadership of the unit has an idealistic influence on its employees. Inspirational motivation and intellectual stimulation from the leaders of the unit also gives the meaning that the leadership has provided good inspirational motivation to its employees and leaders has also provided intellectual encouragement to its employees. Furthermore, our study also provides an overview that leaders who encourage innovation in the planning process or new control system, new structure, and employee development programs are good for the organization. Organizational culture in each unit also illustrates that the involvement, consistency, and adaptation that occurs is good.

The main objective of this research is to see how strategic leadership can influence executive influence on innovation. We found that the top management team tenure of heterogeneity and organizational culture did not have a significant and negative effect which meant that the two variables could not moderate the relationship of strategic leadership and executive influence on innovation. From this study, we learned that in term of government institutions from top management teams and organizational cultures can not have the effect of strengthening or weakening the relationship of strategic leadership and executive influence on innovation. But strategic leadership must be owned by the leader in order to have a positive effect on innovation.

Our research indicates the importance of strategic leadership owned by each unit leader in government institutions in order to achieve organizational change in the field of innovation. Leaders will have a good influence in innovating so that a culture of innovation is created. For 
further research, it is hoped that it can further deepen executive influence on innovation in government institutions.

\section{References}

[1] D. S. Elenkov, W. Judge, dan P. Wright, "Strategic Leadership And Executive Innovation Influence: An International Multi-Cluster Comparative Study," Strateg. Manag. J., vol. 26, no. 7, hlm. 665-682, 2005.

[2] K. Szczepańska-Woszczyna, "Leadership And Organizational Culture As The Normative Influence Of Top Management On EmployeelText Quote Singles Behaviour In The Innovation Process," Procedia Econ. Finance, vol. 34, hlm. 396-402, 2015.

[3] K.-H. Huarng, A. Mas-Tur, dan F. C. Moreno, "Innovation, Knowledge, Judgment, And Decision-Making As Virtuous Cycles,” J. Bus. Res., vol. 88, hlm. 278-281, Jul 2018.

[4] J. C. Sarros, B. K. Cooper, dan J. C. Santora, "Building a Climate for Innovation Through Transformational Leadership and Organizational Culture," J. Leadersh. Organ. Stud., vol. 15, no. 2, hlm. 145-158, Jun 2008.

[5] J. Y. L. Thong dan C. S. Yap, "CEO Characteristics, Organizational Characteristics And Information Technology Adoption In Small Businesses,” Omega, vol. 23, no. 4, hlm. 429-442, Agu 1995.

[6] S. P. Osborne, "Naming the Beast: Defining and Classifying Service Innovations in Social Policy," Hum. Relat., vol. 51, no. 9, hlm. 1133-1154, Sep 1998.

[7] N. King, "Modelling The Innovation Process: An Empirical Comparison Of Approaches," J. Occup. Organ. Psychol., vol. 65, no. 2, hlm. 89-100, Jun 1992.

[8] F. Damanpour dan M. Schneider, "Phases of the Adoption of Innovation in Organizations: Effects of Environment, Organization and Top Managers1," Br. J. Manag., vol. 17, no. 3, hlm. 215-236, Sep 2006.

[9] R. Drazin, "Innovation and entrepreneurship: Practice and principles, by Peter F. Drucker. New York: Harper \& Row, 277 pp., Itextdollar19.95," Hum. Resour. Manage., vol. 24, no. 4, hlm. 509-512, 1985.

[10] R. D. Ireland dan M. A. Hitt, "Achieving And Maintaining Strategic Competitiveness In The 21st Century: The Role Of Strategic Leadership," Acad. Manag. Perspect., vol. 13, no. 1, hlm. 43-57, Feb 1999.

[11] A. C. Cooper dan D. Schendel, "Strategic Responses To Technological Threats," Bus. Horiz., vol. 19, no. 1, hlm. 61-69, Feb 1976.

[12] R. A. Burgelman, "Technology Strategy," dalam The Palgrave Encyclopedia of Strategic Management, Palgrave Macmillan.

[13] A. R. Jassawalla dan H. C. Sashittal, "Strategies of Effective New Product Team Leaders," Calif. Manage. Rev., vol. 42, no. 2, hlm. 34-51, Jan 2000.

[14] V. M. Papadakis, S. Lioukas, dan D. Chambers, "Strategic Decision-Making Processes: The Role Of Management And Context," Strateg. Manag. J., vol. 19, no. 2, hlm. 115147, Feb 1998.

[15] W. J. Ferrier dan D. W. Lyon, "Competitive Repertoire Simplicity And Firm Performance: The Moderating Role Of Top Management Team Heterogeneity," Manag. Decis. Econ., vol. 25, no. 67, hlm. 317-327, Sep 2004.

[16] S. Piereson, "In Search of Excellence: Lessons from Americaltextquotesingles Best-Run Companies. By Thomas J. Peters and Robert H. Waterman, Jr. New York: Harper \& Row, 1982," NASSP Bull., vol. 67, no. 466, hlm. 120-121, Nov 1983. 
[17] S. G. Scott dan R. A. Bruce, "Determinants of Innovative Behavior: A Path Model of Individual Innovation in the Workplace," Acad. Manage. J., vol. 37, no. 3, hlm. 580-607, Jun 1994.

[18] K. B. Lowe, K. G. Kroeck, dan N. Sivasubramaniam, "Effectiveness Correlates Of Transformational And Transactional Leadership: A Meta-Analytic Review Of The Mlq Literature,” Leadersh. Q., vol. 7, no. 3, hlm. 385-425, Sep 1996.

[19] C. F. Fey dan D. R. Denison, "Organizational Culture and Effectiveness: Can American Theory Be Applied in Russia?," Organ. Sci., vol. 14, no. 6, hlm. 686-706, Des 2003.

[20] G. Caire dan G. S. Becker, "Human Capital, A Theoretical and Empirical Analysis with Special Reference to Education," Rev. Économique, vol. 18, no. 1, hlm. 132, Jan 1967.

[21] N. Fondas, "Process Innovation: Reengineering Work Through Information TechnologyProcess Innovation: Reengineering Work Through Information Technology By DavenportThomas H.. Boston, MA: Harvard Business School Press, 1993-326 pages, Itextdollar29,95," Acad. Manag. Perspect., vol. 7, no. 2, hlm. 100-103, Mei 1993.

[22] S. G. Harris, "The Fifth Discipline: The Art And Practice Of The Learning Organization, By Peter Senge, New York: Doubleday/Currency," Hum. Resour. Manage., vol. 29, no. 3, hlm. 343-348, 1990.

[23] A. Perry, "The rise and fall of strategic planning: Reconceiving roles for planning, plans, planners by Henry Mintzberg. New York: The Free Press. 1994. 458 \$ \mathplus\$ xix pages. Itextdollar29.95," J. Prod. Innov. Manag. N. Y. Free Press, vol. 13, no. 3, hlm. 275-278, Mei 1996.

[24] Ohmae.K, "The mind of the strategist: The art of Japanese business," J. Macroecon., vol. 4, no. 4, hlm. 494, Sep 1982.

[25] J. K. Broida, "Competing for the Future: Breakthrough Strategies for Seizing Control of Your Industry and Creating the Markets of TomorrowBy HamelGary and PrahaladC.K., Boston, MA: Harvard Business School Press, 1994-288 pages, hardcover, Itextdollar24.95.," Acad. Manag. Perspect., vol. 8, no. 4, hlm. 91-93, Nov 1994.

[26] R. C. Hoffman dan W. H. Hegarty, "Top Management Influence on Innovations: Effects of Executive Characteristics and Social Culture,” J. Manag., vol. 19, no. 3, hlm. 549-574, Jun 1993. 